\title{
The effect of nutrition, depression, activity scores on mortality in patients with geriatric hip fractures
}

\author{
Geriatrik kalça kırığı hastalarında beslenme, depresyon, aktivite skorlarının mortalite \\ üzerine etkisi
}

\author{
Savaş Çamur ${ }^{1}$, Çağrı Özcan ${ }^{1}$, Mehmet Mesut Sönmez ${ }^{2}$, Sefa Giray Batıbay ${ }^{3}$
}

\begin{abstract}
Aim: Hip fracture causes high mortality rates in elderly patients. Here we investigate the relationship between serum laboratory parameters, bone densitometers, malnutrition, depression and pre-fracture survival activity scores of patients who died within 24 months after surgery for hip fracture.

Methods: 121 patients who underwent surgery for hip fracture between 2013 and 2016 and who met the study criteria were evaluated retrospectively. The patients who died within the first 24 months after surgery were evaluated as Group 1, and the patients who died after 24 months or who were still alive were evaluated as Group 2. Serum parameters before surgery, hip and vertebra bone densitometry were examined. The Barthel and Lawton Life Scale was completed, Mini nutritional assesment (MNA), geriatric depression scala short form (GDS-SF) and preoperative length of stay and BMI were evaluated.

Results: Comparing the parameters between groups, we detected no significant difference between age, BMI, vertebral BMD preoperative length of stay. Albumin, total protein, hip BMD, barthel score, and the lawton scoring system, GDS-FM, MNA showed significant differences between the two groups $(\mathrm{P}<0.05)$. According to the regression analysis, Albumin, total protein, MNA, GDS-SF, Barthel Score and Lawton Scoring Systems showed a significantly correlation in patients with mortality in the first 24 months $(\mathrm{P}<0.05)$.

Conclusion: Geriatric hip fractures have many factors that determine the risk of mortality within the first 24 months. According to our study, low albumin, total protein , malnutrition, high depression as well as low pretreatment activity scores, indicate high mortality risk in the 24 months.
\end{abstract}

Keywords ; Hip fractures, depression, nutrition, geriatric mortality, bone densitometry

\section{Öz}

Amaç: Kalça kırı̆̆ı yaşlı hastalarda yüksek mortalite oranlarına sebep olur. Bu çalışmada kalça kırı̆̆ı nedeniyle ameliyat sonrası 24 ay içinde ölen hastaların serum laboratuvar parametreleri, kemik dansitometreleri, yetersiz beslenme, depresyon ve kırık öncesi sağkalım aktivite skorları arasındaki ilişkiyi araştırdık.

Gereç ve Yöntem: 2013-2016 yılları arasında kalça kırı̆ı nedeniyle ameliyat edilen ve çalışma kriterlerini karşılayan 121 hasta retrospektif olarak incelendi. Ameliyattan sonraki ilk 24 ay içinde ölen hastalar Grup 1, 24 ay sonra ölen veya halen hayatta olan hastalar Grup 2 olarak değerlendirildi. Ameliyat öncesi serum parametreleri, kalça ve vertebra dansitometrisi ölçüldü. Barthel ve Lawton Aktivite Skorları, Mini beslenme değerlendirmesi (MNA), geriatrik depresyon skala kısa formu (GDS-SF) ve preoperatif yatış süresi ve BMI değerlendirilmiştir.

Bulgular: Gruplar arasındaki parametreleri karşılaştırarak yaş, BMI, vertebra dansitometresi, preoperatif yatı̧ süresi arasında anlamlı bir fark saptanmadı. Albümin, total protein, kalça dansitometresi, Barthel ve Lawton Aktivite Skorları, GDS-FM, MNA iki grup arasında anlamlı farklılıklar gösterdi $(\mathrm{P}<0.05)$. Regresyon analizine göre, albumin, total protein, MNA, GDS-SF, Barthel ve Lawton Aktivite Skorları ilk 24 ayda mortalitesi olan hastalarda anlamlı bir korelasyon gösterdi $(\mathrm{P}<0.05)$.

Sonuç: Geriatrik kalça kırıkları ilk 24 ay içinde mortalite riskini belirleyen birçok faktöre sahiptir. Çalışmamıza göre, düşük albümin, total protein, yetersiz beslenme, yüksek depresyon ve düşük aktivite skorları geriatrik kalça kırıklarında ilk 24 ayda yüksek mortalite riskini göstermektedir.

Anahtar Kelimeler; Kalça kırıkları, depresyon, beslenme, geriatrik mortalite, kemik Dansitometrisi
${ }^{1}$ University of Health Sciences, Umraniye Training and Research Hospital, Department of Orthopaedics and Traumatology, Istanbul, Turkey.

${ }^{2}$ University of Health Sciences, Haseki Training and Research Hospital, Department of Orthopaedics and Traumatology, Istanbul, Turkey.

${ }^{3}$ Ankara Meslek Hastalıkları Hastanesi, Department of Orthopaedics and Traumatology, Ankara, Turkey.

\section{ii}

\section{SÇ: 0000-0001-5419-0063}

CÖ: 0000-0002-6651-3322

MMS: 0000-0002-8646-2067

SGB: 0000-0002-6226-6651

Ethics Committee Approval: The study was approved by SBU Sisli Hamidiye Etfal Training and Research Hospital ethical authority. (Project No: $1133.05 / 02 / 2019$ )

Etik Kurul Onayı: Calıșma SBÜ Șişli Hamidiye Etfal Eğitim ve Araştırma Hastanesi etik kurulu tarafindan onaylanmıştır. (Proje No: 1133. 05/02/2019)

Conflict of Interest: No conflict of interest was declared by the authors.

Çıkar Çatışması: Yazarlar çıkar çatışması

bildirmemișlerdir.

Financial Disclosure: The authors declared that this study has received no financial support. Finansal Destek: Yazarlar bu çalıșma için finansal destek almadıklarını beyan etmişlerdir.

Geliș Tarihi / Received: 24.03.2020

Kabul Tarihi / Accepted: 23.06.2020

Yayın Tarihi / Published: 31.08.2020

Sorumlu yazar / Corresponding author:

Çagri Özcan

Adres/Address: University of Health Sciences, Umraniye Training and Research Hospital, Department of Orthopaedics and Traumatology, Elmalikent district, Adem yavuz Street, No:1 34764 Umraniye/Istanbul TURKEY.

e-posta: cagriozcann@gmail.com

Tel/Phone: +905453776013

Copyright $($ ) ACEM 


\section{Introduction}

Hip fractures are often seen in elderly patients, with high mortality and morbidity rates. The average life expectancy in elderly people treated for hip fractures is shorter than those not treated from hip fractures [1]. Many factors play a role in postoperative mortality and morbidity in elderly patients[2]. Whether regional or general anesthesia methods are selected, mortality and morbidity cannot be reduced beyond a certain level[3]. In these patients, concomitant diabetes, hypertension, cardiovascular insufficiency, and lung problems increase the mortality and complications after surgery in these patients [4]. More than $50 \%$ of patients with old hip fractures have three or more chronic diseases[5]. In the literature, several studies had addressed morbidity and mortality in hip fractures, investigating various potentially contributing factors.

Some studies have shown that patients with high potassium, low albumin, and low hemogram have a relatively high mortality[6]. Other studies have reported that osteosarcopenia, muscle imbalans, activity scores are associated with mortality.

Depression is a pathological process that affects the daily activities of patients and reduces the quality of life[7]. This process affects the recovery of patients after surgery. Depression, especially associated with malnutrition, adversely affects the rehabilitation, healing process of the patient after surgery.

In our study, we evaluated malnutrition, depression scale and activity score of patients who were operated for hip fractures and investigated the relationship between the values of mortality and the risk of mortality in the first 24 months. We hypothesized that malnutrition, depression, albumin, total protein, activivity scores and osteoporosis affect mortality in these patients during the first 2 years after surgery.

\section{Material and methods}

Our study was approved by the Ethical Committee of our Institute (Number: 2019/1133). Between 2013 and 2016, 267 patients who were admitted to our hospital due to hip fracture were evaluated retrospectively. The study inclusion criteria were: Patients between the ages of 65 and 100 years, patients with an ASA score of 3 and above, patients who were admitted to our hospital within the first $24 \mathrm{~h}$ after a fracture, PFN Proksimal Femoral Nail, TST Rakor Medical Instruments Inc., Istanbul, Turkey), or patients with hip fractures treated with hemiarthroplasty with cemented and cementless(TST Rakor Medical instruments Co., Istanbul, Turkey). Cement application decision was decided according to hip dorr index. According to Dorr index, those with type A were treated with cementless, type $\mathrm{B}$ and $\mathrm{C}$ with cemented prosthesis. The exclusion criteria were: patients in the intensive care unit preop followed, patients with a fracture of the hip with another fracture, oncology patients, patients with preop or postop dialysis requirements, patients with pathological fractures, patients with a previous hip fracture, patients who have undergone another surgery within the last month, patients using immunosuppressive agents, patients with died during surgery, Patients with less than 24 months follow-up, and patients who have to wait for surgery for more than 7 days.

A total of 121 patients who met the study criteria were evaluated retrospectively. Relatives of the patients were reached from the hospital records. The exact days of death were asked. The patients who died within the first 24 months after the surgery were classified as Group 1, and the patients who died or survived after 24 months were Group 2. All patients were evaluated by a single anesthesiologist. ASA scores were determined. In the first 24 hour after the fractures, venous blood samples were taken, and laboratory parameters were evaluated. In laboratory parameters, albumin, and total protein levels were evaluated in all patients.(Coulter LH 780 Hematology Analyzer, California, USA) All patients' BMIs (Body Mass Indexes) were calculated by asking the patients or their relatives. In the preoperative period, albumin supplements were applied to patients with albumin below 2.5. However, preoperative initial values were included in the study. No special supplements were used in the postoperative period. Densitometry was performed from the intact hips and vertebra. The patient's intact hip was measured with 25 degrees of internal rotation following the following parameters (QDR Series Hologic, Inc., Bed- 97 ford, MA USA): (hip FOV: $113 \times 112$; neck FOV: $4998 \times 15$; total BMD CV: $1.0 \%$; TH: 4.5). The Barthel and Lawton scores were calculated. Preop malnutrition disorders were evaluated by Mini nutritional assesment (MNA) [8]. The results of the MNA score were categorized into 3 groups. Malnourished patients were defined as having a MNA score less than 17 points (It was categorized as 1), risk for malnutrition patients the MNA score was between 17 and 23.5 points (It was categorized as 2) and Patients with good nutrition had a MNA score above 23.5 points (It was categorized as 3). Preop depression condition was evaluated by geriatric depression scale short form (GDS-SF) were evaluated[9]. The results of the GDS-SF score were categorized into 4 groups. Patients with a score of $0-4$ were diagnosed with no depression (It was categorized as 0 ), mild depression with a score of 5-8 (It was categorized as 1), moderate depression with a score of 9-11 (It was categorized as 2 ), and major depression with a score of 12-15(It was categorized as 3).. According to the anesthesiologist's assessment, 40 patients underwent general and 92 patients underwent spinal anesthesia. PFN or hemiarthroplasty was performed according to the type of fracture. All patients were mobilized on the first postoperative day. All patients were given cephazolin ( $1 \mathrm{~g} \mathrm{IV})$ for the prophylaxis of infection on the first day and enoxaparin sodium embolism for the first 4 weeks. The patients were contacted by telephone every month in the postoperative follow-up, and their mortality status was questioned.

\section{Statistical analysis}

While evaluating the findings of the study, IBM SPSS Statistics 22 (IBM SPSS, USA, New York) program was used for statistical analysis. The normal distribution was evaluated by Shapiro-Wilks test. The Mann-Whitney $U$ test was used to evaluate the parameters that did not show a normal distribution.. When the parameters were evaluated by Shapiro-Wilks test, it was seen that the parameters were not distributed homogeneously. The values between the two groups were evaluated by the Mann Whitney U test.

A multivariate logistic regression analysis was used to determine the relationship between the parameters used and mortality in our study. Results of multivariate analyzes were reported as adjusted odds ratios (OR) with $95 \%$ confidence intervals $(\mathrm{CI})$ with a threshold significance at $\mathrm{p}<0.05$.

\section{Results}

One hundred twenty one patients included in the study, 63 were Group 1 and 58 were Group 2. Of 121 patients, 50 were male, and 71 were female. PFN was performed in 70 patients, and hemiarthroplasty was performed in 51 patients. Femoral neck fracture in 46 patients, subtrochanteric fracture in 17 patients, intertrochanteric fracture in 58 patients was seen. Cemented hemiarthroplasty was performed in 37 patients, and cementless hemiarthropasty in 14 patients. 
The mean age of the patients in Group 1 was 82.32 (65$103)$. The mean preoperative BMI was $24,55(18,14-37,10)$. Bone densitometry in spine was measured as $-2.54(0.80--6.60)$. Bone Densitometry in hip at $-3.08(0.70--4.90)$. When the laboratory parameters of the patients in Group 1 are evaluated, the values were: albumin $2.86 \mathrm{~g} / \mathrm{dL}$ (2.1-4.78); total protein, 5.58 $\mathrm{g} / \mathrm{dL}$ (3.70-7.93);. The Barthel score of the patients in Group 1 was 2,54 (1-3), and the Lawton score was 2.28 (0-5). The mean preoperative hospitalization time of the patients in Group 1 was 2.4 (1-6) days. According to GDS-SF there were no depression in 4 patients, mild depression in 22 patients, moderated depression in 30 patients and major depression in 7 patients. According to MNA scores, 12 patients had good nutrition and 35 patients had risk for malnutrition and 16 patients had malnutrition in Group 1

The mean age of the patients in Group 2 was 78.80 (6590). The mean preoperative BMI was 25.95 (18.17-35.70). The mean spine densitometry was -2,18 (0.90--5.2) and hip densitometry was $-2.5(0.6--4.30)$. When laboratory parameters of the patients in Group 2 are evaluated, the values were: mean albumin, $3.16 \mathrm{~g} / \mathrm{dL}$ (2-4.6); total protein, $6.12 \mathrm{~g} / \mathrm{dL}$ (4.9-7.76) The mean Barthel score of the patients in Group 2 was 3.42 (1-5) and the Lawton score was $4.94(0-8)$. The mean preoperative hospitalization period of the patients in Group 2 was 2.1 (1-7) days. When GDS-SF was examined in Group 2 patients, 21 patients had no depression, 25 patients had mild depression and 10 patients had moderated depression. There was no major depression sign in group 2 patients. According to MNA scores, 42 patients had good nutrition, 14 had risk for malnutrition and 2 had malnutrition in group 2 patients.

The parameters between the two groups were evaluated using the Mann Whitney $U$ test. We detected no significant difference between age, BMI, vertebra BMD, preoperative hospitalization (all $\mathrm{P}>0.05$ ). albumin, total protein, Hip BMD, MNA, GDS-SF, the Barthel Score, and the Lawton scoring system showed significant differences between the two groups $(\mathrm{p}<0.05)$ (Tables 1 and 2).

Table 1. Demographic findings, serum parameters, bone measurements of both groups, Preop Hospitalization.

\begin{tabular}{|l|l|l|l|l|}
\hline & Total & Group 1 & Group 2 & P Value* \\
\hline AGE & $\begin{array}{l}80,45 \pm 8,06 \\
(65-103)\end{array}$ & $\begin{array}{l}82.32 \pm 5,99 \\
(68-100)\end{array}$ & $\begin{array}{l}78,80 \pm 6,96 \\
(65-90)\end{array}$ & 0,107 \\
\hline BMI & $\begin{array}{l}25,29 \pm 4,17 \\
(18,14-37,10)\end{array}$ & $\begin{array}{l}24,55 \pm 4,08 \\
(18,14-37,10)\end{array}$ & $\begin{array}{l}25,95 \pm 4,17 \\
(18,17-35,70)\end{array}$ & 0,089 \\
& $3,01 \pm 0,53$ & $2,86 \pm 0,51$ & $3,16 \pm 0,5$ & $\underline{0,001}$ \\
\hline ALBUMIN & $(2,00-4,78)$ & $(2,1-4,78)$ & $(2-4,60)$ & \\
\hline TOTAL & $5,86 \pm 0,79$ & $5,58 \pm 0,84$ & $6,12 \pm 0,65$ & $\underline{0,001}$ \\
PROTEIN & $(3,70-7,93)$ & $(3,7-7,93)$ & $(4,90-7,76)$ & \\
\hline SPINE BMD & $-2,35 \pm 1,57$ & $-2,54 \pm 1,64$ & $-2,18 \pm 1,49$ & 0,25 \\
& $(0,90--6,60)$ & $(0,80--6,60)$ & $(0,90--5,2)$ & \\
\hline HIP BMD & $-2,7 \pm 0,92$ & $-3,08 \pm 0,86$ & $-2,5 \pm 0,89$ & 0,001 \\
& $(0,70--4,90)$ & $(0,7---4,9)$ & $(0,6--4,30)$ & \\
\hline Preop & $2,3 \pm 0,89$ & $2,4 \pm 0,87$ & $2,1 \pm 0,92$ & 0,48 \\
Hospitalization & $(1-7)$ & $(1-6)$ & $(1-7)$ & \\
(Day) & & & & \\
\hline
\end{tabular}

Body Mass Index (BMI); Bone Mineral Density (BMD), * Mann Whitney $\mathrm{U}$ test $\mathrm{p}<0.05$ statistically significant.

According to the Multinomial Logistic Regression Analysis after correcting various covariates (age, gender, BMI, preoperative hospitalization, surgery procedure, fracture type, ASA scores) the parameters examined in the study. Albumin, total protein, MNA, GDS-SF, the Barthel Score, and the Lawton scoring systems were significantly different in patients with mortality in the first two years $(\mathrm{p}<0.05)$. (Table 3$)$ There was no significant relationship between bone densitometry and mortality in the first 2 years according to regression analysis.

Table 2. Functional scores, Mini nutritional assessment (MNA) and geriatric depression scala short form (GDS-SF) of both groups.

\begin{tabular}{|l|l|l|l|l|}
\hline & Total & Group 1 & Group 2 & $\begin{array}{l}\text { P } \\
\text { Value* }^{*}\end{array}$ \\
\hline BARTHEL & $\begin{array}{l}3 \pm 0,8 \\
(1-5)\end{array}$ & $\begin{array}{l}2,54 \pm 0,61 \\
(1-3)\end{array}$ & $\begin{array}{l}3,42 \pm 0,91 \\
(1-5)\end{array}$ & $\underline{\mathbf{0 , 0 0 1}}$ \\
\hline LAWTON & $3,6 \pm$ & $2,28 \pm 1,55$ & $4,94 \pm 2,21$ & $\underline{\mathbf{0 , 0 0 1}}$ \\
& 2,3 & $(0-5)$ & $(0-8)$ & \\
& $(0-8)$ & & $2,9 \pm 0,8$ & $\underline{\mathbf{0 , 0 0 1}}$ \\
\hline MNA** & $2,45 \pm 0,7$ & $2,12 \pm 0,5$ & $(1-3)$ & \\
\hline GDS-SF*** & $(1-3)$ & $(1-3)$ & $0,82 \pm 0,5$ & $\underline{\mathbf{0 , 0 0 1}}$ \\
& $1,2 \pm 0,4$ & $1,61 \pm 0,7$ & $(0-2)$ & \\
\hline
\end{tabular}

MNA: Mini nutritional assessment, GDS-SF: Geriatric depression scala short form, * Mann Whitney U test $\mathrm{p}<0.05$ statistically significant, **MNA score were categorized into 3 groups, ***GDS-SF score were categorized into 4 groups.

Table 3. Models adjusted for age, gender, BMI, preoperative hospitalization, surgery procedure, fracture type

\begin{tabular}{|c|c|c|c|c|c|}
\hline & B & $\begin{array}{l}\text { Std } \\
\text { Error }\end{array}$ & $\begin{array}{l}\text { Odd } \\
\text { Ratio }\end{array}$ & $\begin{array}{l}\% 95 \\
\text { Confidence } \\
\text { interval }\end{array}$ & $\begin{array}{l}\mathrm{P} \\
\text { Value* }\end{array}$ \\
\hline MNA & 1,8 & 0,6 & 0,19 & $0,06-0,71$ & 0,014 \\
\hline GDS-SF & 1,55 & 0.33 & 1,12 & $1,3-1,1$ & 0,044 \\
\hline BARTHEL & $-1,7$ & 0,41 & 1,18 & $1,08-1,40$ & 0,001 \\
\hline LAWTON & $-0,7$ & 0,37 & 0,49 & $0,34-0,69$ & 0,032 \\
\hline T.PROTEIN & $-1,6$ & 0,6 & 0,3 & $0,9-1,2$ & 0,041 \\
\hline ALBUMIN & $-0,2$ & 0,8 & 0,9 & $1,1-1,5$ & 0,022 \\
\hline $\begin{array}{l}\text { SPINE } \\
\text { BMD }\end{array}$ & 1,1 & 0,6 & 1,2 & $0,8-21,5$ & 0,08 \\
\hline HIP BMD & 0,9 & 0,3 & 1,5 & $1,3-2,1$ & 0,106 \\
\hline
\end{tabular}

Std error: Standart Error, B: Coefficient of variables, MNA: Mini nutritional assessment, GDS-SF: Geriatric depression scala short form BMD: Bone Mineral Density, *: Multinomial Logistic Regression Analysis

\section{Discussion}

In recent years and because of advances in medicine, we are living longer, and the elderly population is increasing rapidly[1]. Thus, hip fractures are more common due to the increase in the elderly population. The comorbidities of these patients increase the difficulty of the surgery. In these patients, the mortality rates within the first year after surgery have been reported as $22 \%$ [10]. Franzo et al. reported the mortality rate in geriatric hip fractures in the first 6 months as $20 \%$, and as $25 \%$ in the first year[11]. Roche et al. reported a mortality rate of $33 \%$ after 1 year[12]. These rates are altered according to the comorbidities of these patients and the time before surgery [13]. Pre-fracture functional status and muscle activity are the factors determining the post-surgical mortality rate[14].

Malnutrition in geriatric patients is an important factor affecting mortality[15]. In a meta-analysis study by Li et al., low serum albumin levels were found to be the most important predictors of hospital death risk and complication increase in geriatric hip fracture patients[16]. These authors also stated that the mortality rate was high in patients with low levels of malnutrition. In our study, albümin, total protein levels and MNA were found to be very low in the patients who were lost within the first 2 years. In these patients, improvement of albumin supplementation and malnutrition before and after 
surgery might lead to a decrease in the mortality rates of patients. There are many publications in the literature that postoperative rehabilitation and patients recovery are more difficult in patients with poor nutritional status. A metaanalysis study by Peeters CM et al showed that patients with poor nutritional status had a very low return to pre-fracture health status [17] . Malafarina et al. In the metaanalysis study, malnutrition rate was $18.7 \%$ in patients evaluated with MNA score, whereas the prevalence was $45.7 \%$ in the case of malnutrition assessed by albumin protein and BMI rates in hip fracture[18]. In this study although surgical techniques improved, 1-year mortality rate was 30\% in these patients. In our study, especially in patients with low MNA scores, severe albumin and total protein decreased were observed in the group with a high mortality rate in the first two years. Van Wissen et al. Reported that 1-year mortality rate was $46 \%$ in patients with poor MNA scores and decreased to $7 \%$ in patients with good MNA scores in 226 cases of hip fracture patients[19]. In our study, a result consistent with the literature was observed.

In recent years, several studies have investigated the relationship between depression and hip fractures. In a study by Bi-Hua Cheng et al., They showed that $61 \%$ of patients with major depression had hip fractures more frequently than those without depression. However, in the same study, there was no significant difference between patients with less severe depressive disorder and without depressions[20]. According to our study, we think that depression is the cause of mortality in hip fracture. Andrade $\mathrm{C}$ showed that hip fracture was more common in patients with depression[21]. He questioned whether this was due to depression or antidepressant drugs. However, Branstrom et al showed that the risk of fracture was significantly lower after antidepressant use[22]. In a retrospective study by Maharlounei et al., Depression showed a significant effect on mobilization and recovery of patients within 6 months postoperatively. When these patients do not receive psychiatric support, they become more bedridden and patients recovery becomes more difficult in these patients [23]. In this case the depression scale of the patients more severe. It is especially important to recognize and treat depression in these patients. And we think that older osteoporotic hip fractures have more depression than expected.

GDS-SF was filled before surgical treatment in the patients included in the study. The high GDS-SF of these patients was found to be related to the mortality of patients after treatment. Depression is a pathological process that affects patients' daily care and quality of life. If the scale of depression is high in these patients, psychiatric support is required for this pathological process. In the meta-analysis study conducted by Shi TT et al., The incidence of hip fracture is more common in individuals with depression than in normal individuals. The mortality risk is also very high in these patients [24].

In our study, Barthel and Lawton's scoring system was used to evaluate the daily life activities of patients before hip fracture. Living activities prior to fracture show muscle imbalance of patients. This causes faster recovery and mobilization of the patient after surgery. Muscle imbalance also varies proportionally to bone density [25]. Türkmen et al. reported that bone density and gluteus maximus muscle mass were correlated with hip fracture in geriatric patients, and they show that bone density decreased in patients with low muscle mass [26]. In our study, daily life activity scores were significantly lower in patients who died within the first 24 months. In our study, no significant effect of osteoporosis on mortality was observed in the first two years. Osteoporosis increases the risk of fracture. However, since osteoporosis treatment indirectly increases activity in these patients, we think that it increases muscle imbalance and activity scores. Although there is no significant mortality, osteoporosis treatment should be given after fracture in these patients. Additionally preoperative muscle activation and strengthening of the muscle gives a better result after surgery [27].

Based on these data, we think that improved nutrition, treatment of patients with signs of depression, psychological rehabilitation and early physiotherapy would likely decrease the mortality rate during the early period postoperative period.

Limitations of this study include its retrospective design. Also, comorbidities were not investigated in the study group. Comorbidities might affect the mortality rate of patients, regardless of laboratory values [28,29]. Laboratory values are likely affected by multiple different factors. Therefore, we attempted to apply strict exclusion criteria in our study. We found that the number of patients studied in both groups was adequate based on comparison to similar studies in the literature.

Based on our findings, we propose that, low albumin, and total protein levels, depression, low malnutrition in elderly patients with hip fractures are important risk factors affecting mortality in the first 2 years. In addition, the preoperative activity status of the patient is related to mortality in the first 2 years.

\section{References}

1. Sheehan KJ, Sobolev B, Guy P.(2017) Mortality by Timing of Hip Fracture Surgery: Factors and Relationships at Play. J Bone Joint Surg Am. 2017: 18;99(20):e106

2. Katsoulis M, Benetou V, Karapetyan T et al.(2017) Excess mortality after hip fracture in elderly persons from Europe and the USA: the CHANCES project. J Intern Med. 281(3):300-310.

3. Neuman MD, Rosenbaum PR, Ludwig JM, Zubizarreta JR, Silber JH (2014) Anesthesia technique, mortality, and length of stay after hip fracture surgery. JAMA. 311(24):2508-17.

4. González-Zabaleta J, Pita-Fernandez S, Seoane-Pillado T, LópezCalviño B, Gonzalez-Zabaleta JL. (2016) Comorbidity as a predictor of mortality and mobility after hip fracture. Geriatr Gerontol Int. 16(5):561-9

5. Boyd CM, McNabney MK, Brandt N et al. (2012) Guiding principles for the care of older adults with multimorbidity: an approach for clinicians: American Geriatrics Society Expert Panel on the Care of Older Adults with Multimorbidity. J Am Geriatr Soc. 60(10):E1-E25

6. Sedlář M, Kvasnička J, Krška Z, Tománková T, Linhart A.(2015) Earley and subacute inflammatory response and long-term survival after hip trauma and surgery. Arch Gerontol Geriatr. 60(3):431-6

7. Alexiou KI, Roushias A, Varitimidis SE, Malizos KN.(2018) Quality of life and psychological consequences in elderly patients after a hip fracture: a review. Clin Interv Aging. 24;13:143-150.

8. Guigoz Y, Vellas B, Garry PJ.(1996) Assessing the nutritional status of the elderly: The Mini Nutritional Assessment as part of the geriatric evaluation. Nutr Rev. 54(1 Pt 2):S59-65

9. Weng CF, Lin KP, Lu FP et al.(2019) Effects of depression, dementia and delirium on activities of daily living in elderly patients after discharge. BMC Geriatr. 11;19(1):261.

10. Imai N, Endo N, Hoshino T, Suda K, Miyasaka D, Ito T.(2016) Mortality after hip fracture with vertebral compression fracture is poor. J Bone Miner Metab. 34(1):51-4

11. Franzo A, Francescutti C, Simon G. Risk factors correlated with postoperative mortality for hip fracture surgery in the elderly: a population-based approach. Eur J Epidemiol 2005;20:985-91.

12. Roche JJ, Wenn RT, Sahota O, Moran CG. Effect of comorbidities and postoperative complications on mortality after hip fracture in elderly people: prospective observational cohort study. BMJ 2005;331:1374.

13. Yoo J, Lee JS, Kim S.(2019) Length of hospital stay after hip fracture surgery and 1-year mortality. Osteoporos Int. 30(1):145-153

14. Ishidou Y, Koriyama C, Kakoi H.(2017) Predictive factors of mortality and deterioration in performance of activities of daily living after hip fracture surgery in Kagoshima, Japan. Geriatr Gerontol Int. 17(3):391-401.

15. Torbergsen AC, Watne LO, Frihagen F, Wyller TB, Mowè M.(2019) Effects of nutritional intervention upon bone turnover in elderly hip fracture patients. Randomized controlled trial. Clin Nutr ESPEN. 29:52-58. 
16. Li S, Zhang J, Zheng H, Wang X, Liu Z, Sun T.(2019) Prognostic role of serum albumin, total lymphocyte count, and mini nutritional assessment on outcomes after geriatric hip fracture surgery: a metaanalysis and systematic review. J Arthroplasty. 34(6):1287-1296.

17. Peeters CM, Visser E, Van de Ree CL, Gosens T, Den Oudsten BL, De Vries J.(2016) Quality of life after hip fracture in the elderly: A systematic literature review. Injury. 47(7):1369-82.

18. Malafarina V, Reginster JY, Cabrerizo $\mathrm{S}$, Bruyère $\mathrm{O}$, Kanis JA, Martinez JA, Zulet MA.(2018) Nutritional Status and Nutritional Treatment Are Related to Outcomes and Mortality in Older Adults with Hip Fracture. Nutrients. 10(5). pii: E555. doi: 10.3390/nu10050555.

19. van Wissen J, van Stijn MF, Doodeman HJ, Houdijk AP.(2016) Mini Nutritional Assessment and Mortality after Hip Fracture Surgery in the Elderly. J Nutr Health Aging. 20(9):964-968.

20. Cheng BH, Chen PC, Yang YH, Lee CP, Huang KE, Chen VC.(2016) Effects of depression and antidepressant medications on hip fracture: A population-based cohort study in Taiwan. Medicine (Baltimore). 95(36):e4655.

21. Andrade C. (2019) Antidepressant Drugs and the Risk of Hip Fracture in the Elderly: Is There More to It Than Confounding by Indication? J Clin Psychiatry 30;80(4). pii: 19f12999.

22. Brännström J, Lövheim H, Gustafson Y, et al.(2019) Association between antidepressant drug use and hip fracture in older people before and after treatment initiation. JAMA Psychiatry;76(2):172179.

23. Maharlouei N, Jafarzadeh F, Lankarani KB. (2019) Factors affecting recovery during the first 6 months after hip fracture, using the decision tree model. Arch Osteoporos. ;14(1):61.

24. Shi TT, Min M, Zhang Y.(2019) Depression and risk of hip fracture: a systematic review and meta-analysis of cohort studies. Osteoporos Int.;30(6):1157-1165

25. Oliveira A, Vaz C. (2015) The role of sarcopenia in the risk of osteoporotic hip fracture. Clin Rheumatol.;34(10):1673-80

26. Turkmen I, Ozcan C. (2019) Osteosarcopenia increases hip fracture risk: A case-controlled study in the elderly. J Back Musculoskelet Rehabil.;32(4):613-618.

27. Turkmen I, Altun G. Increasing the Deltoid Muscle Volume Positively Affects Functional Outcomes After Arthroscopic Rotator Cuff Repair Knee Surg Sports Traumatol Arthrosc 2019 Jan;27(1):259-266

28. Harris MJ, Brovman EY, Urman RD. (2019) Clinical predictors of postoperative delirium, functional status, and mortality in geriatric patients undergoing non-elective surgery for hip fracture. J Clin Anesth. ;58:61-71. doi: 10.1016/j.jclinane.2019.05.010.

29. Kim JW, Kim DH, Jang EC, Lee YK, Koo KH, Ha YC. (2019) Mortality and its risk factors in nonagenarians after hip fractures. J Orthop Sci. 24(5):850-854 